\title{
SORT maneuver: ease and safety for the practitioner and the patient
}

\author{
Mahdi Najafi, ${ }^{1,2^{*}}$ (D)
}

I read with interest the report of a randomized clinical trial by Sanaie et al. on the comparison of SORT maneuver versus a conventional technique of neck flexion lateral pressure (NFLP) for nasogastric tube (NGT) insertion in ICU-admitted patients [1]. This publication provides evidence for a greater ease of NGT insertion using SORT. Moreover, the success rate was much higher with SORT as compared to NFLP. The study looks flawless in methodology and straight forward in reporting the outcome results with a clever categorization for ease of insertion. Nevertheless, a general drawback is a lack of standard definitions for the favorable outcome like the time span attributable to "ease of insertion" and the determinants for "insertion failure".

With regard to safety, they showed that the rate of complications was less in SORT compared to the other technique even though the difference was not significant. The power of study for this purpose, however, seems insufficient and a larger sample size is required to obtain a significant difference. Moreover, compared to the other complications studied, bleeding is more serious and more complex for which a kind of grading or scoring may be helpful for delineation of the severity.

A highlight from this study was that SORT is easy to be learnt by unskilled healthcare providers. I suggest the measurement of learning curve to support this claim. Then, it would be served as an advantage in demanding

This comment refers to the article available online at https://doi.org/10.1186/ s13613-020-00696-2.

*Correspondence: mahdi.najafi@uwo.ca; mahdinajafikoo@gmail.com 1 Department of Medical Biophysics, Western University, Room M402, Medical Sciences Building, 1151 Richmond St, London, ON N6A 3K7,

Canada

Full list of author information is available at the end of the article situations such as COVID-19 outbreak where trained personnel are overwhelmed by ICU overload [2]. The authors correctly mentioned the low number of providers and not including pediatric and high-risk groups as limitations. I'd like to add two other suggestions: studying hemodynamic response and comparing SORT with techniques that use equipment [3]. Hemodynamic compromise is a concern in cardiac and critically ill patients because of increasing myocardial oxygen demand. Patients with uncontrolled hypertension are even at greater risk [4]. The risk also theoretically increases when we insert NGT using laryngoscope with/without Magill forceps or using glidescope. SORT maneuver is devoid of both due to its smooth process and anatomical approach $[5,6]$. These two proposals are among the issues to be addressed by future research projects on SORT maneuver.

\section{Acknowledgements \\ None.}

\section{Authors' contributions}

The author read and approved the final manuscript.

\section{Authors' information}

Dr. Najafi is trained in anesthesiology, intensive care and cardiac anesthesia. He is associate professor of anesthesiology at Tehran Heart Center, affiliated to Tehran University of Medical Sciences and adjunct professor at Schulich School of Medicine, Western University.

Funding

None.

Availability of data and materials Not applicable.

Ethics approval and consent to participate

Not applicable.

Consent for publication

Not applicable. 


\section{Competing interests}

The author declares that he has no competing interests.

\section{Author details}

1 Department of Medical Biophysics, Western University, Room M402, Medical Sciences Building, 1151 Richmond St, London, ON N6A 3K7, Canada. ${ }^{2}$ Department of Anesthesiology, Tehran Heart Center, Tehran University of Medical Sciences, Tehran, Iran.

Received: 27 August 2020 Accepted: 21 November 2020

Published online: 30 November 2020

\section{References}

1. Sanaie S, Mirzalou N, Shadvar K, et al. A comparison of nasogastric tube insertion by SORT maneuver (sniffing position, NGT orientation, contralateral rotation, and twisting movement) versus neck flexion lateral pressure in critically ill patients admitted to ICU: a prospective randomized clinical trial. Ann Intensive Care. 2020;10:79. https://doi.org/10.1186/s13613-02000696-2.
2. Aziz S, Arabi YM, Alhazzani W, et al. Managing ICU surge during the COVID-19 crisis: rapid guidelines. Intensive Care Med. 2020;46:1303-25. https://doi.org/10.1007/s00134-020-06092-5.

3. Sanaie S, Mahmoodpoor A, Najafi M. Nasogastric tube insertion in anaesthetized patients: a comprehensive review. Anaesth Intensive Ther. 2017:49:57-65.

4. Whelton PK, Carey RM, Aronow WS, Casey DE, Collins KJ, Dennison C, et al. 2017 ACC/AHA/AAPA/ABC/ACPM/AGS/APhA/ASH/ASPC/NMA/ PCNA Guideline for the prevention, detection, evaluation, and management of high blood pressure in adults. Hypertension. 2018;71:e13-115.

5. Najafi M, Golzari S. SORT maneuver for nasogastric tube insertion. Anaesthesia. 2016;71:351-351.

6. Najafi M. Nasogastric tube insertion easily done: the SORT maneuver. Indian J Crit Care Med. 2016;20:492-3.

\section{Publisher's Note}

Springer Nature remains neutral with regard to jurisdictional claims in published maps and institutional affiliations.

\section{Submit your manuscript to a SpringerOpen ${ }^{\circ}$ journal and benefit from:}

- Convenient online submission

- Rigorous peer review

- Open access: articles freely available online

- High visibility within the field

- Retaining the copyright to your article

Submit your next manuscript at $\gg$ springeropen.com 